IZA DP No. 4693

Do Legal Immigrants and Natives Compete in the Labour Market? Evidence from Catalonia

Luis Diaz-Serrano

January 2010 


\title{
Do Legal Immigrants and Natives Compete in the Labour Market? Evidence from Catalonia
}

\author{
Luis Diaz-Serrano \\ Universitat Rovira i Virgili \\ and IZA
}

\author{
Discussion Paper No. 4693 \\ January 2010
}

IZA

P.O. Box 7240

53072 Bonn

Germany

Phone: +49-228-3894-0

Fax: +49-228-3894-180

E-mail: iza@iza.org

\begin{abstract}
Any opinions expressed here are those of the author(s) and not those of IZA. Research published in this series may include views on policy, but the institute itself takes no institutional policy positions.

The Institute for the Study of Labor (IZA) in Bonn is a local and virtual international research center and a place of communication between science, politics and business. IZA is an independent nonprofit organization supported by Deutsche Post Foundation. The center is associated with the University of Bonn and offers a stimulating research environment through its international network, workshops and conferences, data service, project support, research visits and doctoral program. IZA engages in (i) original and internationally competitive research in all fields of labor economics, (ii) development of policy concepts, and (iii) dissemination of research results and concepts to the interested public.
\end{abstract}

IZA Discussion Papers often represent preliminary work and are circulated to encourage discussion. Citation of such a paper should account for its provisional character. A revised version may be available directly from the author. 
IZA Discussion Paper No. 4693

January 2010

\section{ABSTRACT \\ Do Legal Immigrants and Natives Compete in the Labour Market? Evidence from Catalonia ${ }^{*}$}

The precondition for labour-market competition between immigrants and natives is that both are willing to accept jobs that do not differ in quality. To test this hypothesis, in this paper we compare the working conditions between immigrants and natives in Catalonia. Comparing immigrants' working conditions in relation to their native counterparts is not only a useful analysis for studying the extent to which immigrants and low-skilled native workers are direct competitors in the labour market, but also allows us to contribute to the literature on this issue by moving away from the conventional approach used in previous studies. Our results indicate that: i) natives and immigrants display a different taste for job (dis)amenities; ii) Catalan-born workers might be in direct competition with EU15 immigrants, while nonCatalan Spanish workers might be competing with Latin American immigrants, and; iii) African-born immigrants are the group in the Catalan workforce that by far face the worst working conditions.

JEL Classification: J28, J61, J81

Keywords: job quality, working conditions, immigration, job satisfaction

Corresponding author:

Luis Diaz-Serrano

Department of Economics

Universitat Rovira i Virgili

Av. de la Universitat, 1

43204 Reus

Spain

E-mail: luis.diaz@urv.cat

\footnotetext{
* The author would like to acknowledge the financial support of the Spanish Ministry of Education (grant number SEJ2007-66318) and the Regional Government of Catalonia-AGAUR (grant number 2008 ARAF1 00005).
} 


\section{Introduction}

Two majors areas of enquiry in the literature regarding immigration and the labour market are: i) how labour market outcomes of native workers are affected by the presence of immigrants, and; ii) how host labour markets assimilate immigrant workers. The first branch of study looks into the effect of immigration on the employment opportunities of native workers (LaLonde and Topel, 1991; Card, 2001; Borjas, 2003), on their wages (Friedberg and Hunt, 1995; Pischke and Vellking, 1997; Borjas, 1999; Zorlu and Hartog, 2005) and their entrepreneurship activities (Borjas, 1986; Fairlie and Meyer, 1996; Basu, 1998; Clark and Drinkwater, 1998; Lofstrom, 2002). The second branch, the assimilation theory first introduced by Chiswick in 1978, states that immigrants' wages will tend to converge with their equally qualified native counterparts (see also Borjas, 1985). This “catch-up” process is due to the fact that immigrants will acquire new skills appropriate to the host labour market. Several studies have also focussed on testing this assimilation process in other aspects of the labour market, such as the employment opportunities of immigrant workers.

Since Grossman’s (1982) seminal paper, the degree of substitutability and competition in the labour market between natives and immigrants has also received considerable attention. Previous international studies suggest that the degree of substitution between immigrant and native workers is fairly small. However, the most recent evidence is not unequivocal and academic debate on this issue is becoming quite controversial (Altonji and Card, 1991; Gang and Rivera-Batiz, 1994; Hamermesh, 1998; Card, 2001; Ottaviano and Peri, 2005, 2008; Borjas et al. 2003, 2008). We agree with Hammermesh (1998) that the precondition for labour-market competition between immigrants and natives is that both are willing to accept jobs that do not differ in 
quality. On the other hand, if competition does not exist, then immigrants accept jobs with disamenities that natives would probably find unacceptable. The latter assumption would imply complementarity. That is, immigrants are viewed as workers who are willing to take what we can define, according to natives’ standards, as bad jobs. This is precisely the most common argument in favour of immigration. Meanwhile, the widely held popular belief that immigrant workers are willing to accept lower wages than their native counterparts for the same jobs, i.e. substitutability, is the primary argument against immigration. Although these are crucial aspects of immigration economics and the labour market, studies comparing the quality of jobs between immigrants and natives are practically non-existent. Hammermesh (1998) analysed the quality of jobs for immigrants and native whites, blacks and Hispanics in the US. Gazioglu and Sloane (1994) looked for the existence of compensating wage differentials for job disamenities in the immigrant workforce in the UK.

In this paper we compare the working conditions of immigrants and natives in Catalonia. The comparison of immigrants' working conditions in relation to their native counterparts is not only a useful tool in studying the extent to which immigrants and low-skilled native workers are complementary or substitutive, but also, in line with Hamermesh (1998), it allows us to contribute to the literature by moving a step away from the conventional approach used in previous studies. Our study uses cross-section data from the Health Survey of Catalonia 2006 (ESCA2006). We split native workers into two groups, Catalan-born and non-Catalan-born Spanish workers. The reason for making this distinction is that if competition exits, it is more likely that immigrants are competing with non-Catalan-born Spanish migrants than with Catalan-born workers. Most of these non-Catalan-born Spanish workers are low-skilled workers who migrated 
to Catalonia from the poorer southern Spanish regions during the 1960s, 1970s and 1980s.

The aim of this study is twofold. On the one hand, we estimate the effect of different working conditions on workers' utility. We conduct separate analyses by birthplace. This analysis allows us to disentangle which working conditions natives and immigrants workers find (un)acceptable. According to the precondition for competition defined above, we find this analysis is crucial in order to determine the existence of competition/complementarity between native and immigrant workers. On the other hand, we test whether immigrants effectively suffer worse working conditions than natives in their jobs. The empirical analysis carried out here allows us to answer some interesting questions: i) Do immigrants derive a different (dis)utility than natives from the same job (dis)amenities?; ii) Does competition really exist?; and iii) If substitution exists, what is the mechanism by which such processes arise?

In keeping with the aims described above, this paper is structured as follows. In section 2 we briefly overview the different waves of migration to Catalonia during the last few decades. Section 3 presents the conceptual framework. In section 4 we describe the dataset and in section 5 we present the empirical analysis. Finally, section 6 contains a summary and the main conclusions.

\section{Internal migration and immigration in Catalonia}

Catalonia is one of the seventeen Spanish regions, called Comunidades Autonomas (CAs) since 1978. The division of Spain into CAs is not based on a federal system like the Länder in Germany or the states in the US. The Spanish government is not fully decentralized, however, in recent years the degree of autonomy enjoyed by Spanish CAs 
has increased remarkably. For instance, each CA can fully manage and partially govern its own health and education system. However, CAs cannot govern labour market or immigration policies. Catalonia is located in the north-east of Spain. It is similar in land area to Denmark, the Netherlands or Switzerland, and its population (7.3 million in 2006) is about half that of the Netherlands, a quarter larger than the Danish population, the same size as the Swiss population and almost twice the Irish population. In absolute terms, the GDP of Catalonia is similar to that of Greece, Denmark, Ireland and Finland. In relative terms, GDP per capita in Catalonia is similar to that of Germany, Italy, France and Belgium, 30\% higher than that of the EU27, 20\% higher than that of the EU15 and 25\% higher than that of Spain. The case of Catalonia is quite interesting because the immigrants coming from Africa, Latin America and Eastern Europe over the last decade have met with Spanish migrants that came between the 1960s and 1980s from the poorer southern Spanish regions. Furthermore, Catalonia is a bilingual region where the Catalan language has become a considerable barrier in the labour market for some types of jobs.

During the second half of the $20^{\text {th }}$ century Spain experienced a very intensive process of internal migration. This process was especially active between the late 1950s and the 1980s. Internal migration was unidirectional, from the poorer regions of Andalusia, Extremadura, Murcia and Galicia to the richer regions of Catalonia, Basque Country and Madrid. ${ }^{1}$ The Spanish migratory flows mainly consisted of low-skilled workers that moved from poor rural areas to highly industrialized urban areas. These migratory flows affected more than four million people, of which more than one million ended up in Catalonia. This has led to today's situation in which one quarter of the

\footnotetext{
${ }^{1}$ See Bover.and Velilla (2002) for a historical overview of internal migration flows in Spain during the $20^{\text {th }}$ century.
} 
workforce in Catalonia is made up of Spaniards not born in Catalonia. The primary problems these internal migrants face are that they are generally not well educated and they are an aging segment of the population. Therefore, the majority of them have not been able to assimilate the intensive process of technological change experienced in developed economies during the 1990s.

After four decades of intensive internal migration flows, during the last decade immigration from undeveloped and developing countries has also become a very important and controversial issue in Spain. In 1990 there were 407,647 foreign-born legal residents in Spain, while in 2006 this number rose to 2,804,303, of which approximately 25\% live in Catalonia. Non-Spanish-born legal residents represent about 8.4\% of the workforce in Catalonia. Both non-Catalan-born Spanish and immigrants tend to be employed in low-skilled jobs. Hence, one might expect that if competition exists, it takes place mostly between immigrants and the non-Catalan Spanish population that migrated to Catalonia between the1950s and 1980s.

In table 1 we report the distribution of occupations and industries according to birthplace. EU15 and Catalan-born workers report a higher rate of employment in managerial, professional and technical occupations (59.3 and 41.6 percent, respectively). African and Latin American workers report a smaller rate of occupation in these types of jobs (5.8 and 18.7\%, respectively). African and Latin American-born workers show a greater propensity to be employed in low-skilled jobs (58.1 and 38.8\%, respectively), while the smallest rate of occupation in these types of jobs is reported by EU15 and Catalan-born workers (12.8 and 14.9\%, respectively). Data on occupation rates by industry show that almost $50 \%$ of African-born workers are employed in agriculture and construction, while this percentage is around 27\% for Eastern European 
workers and less than $20 \%$ for the remaining groups of workers. Almost $40 \%$ of Asianborn workers are employed in the restaurant and catering or commercial sectors. According to the employment rates reported in table 1, Catalan- and EU15-born workers are more likely to be employed in the same occupations and industries. A similar conclusion can be reached if we compare non-Catalan-born Spanish and Eastern European and Latin American workers. Finally, Asian- and African-born workers tend to concentrate employment in very specific occupations-industries.

[Insert table 1 around here]

\section{Conceptual framework}

As we mentioned in the introduction, one of the aims of this study is to determine whether immigrants and natives derive different utility from the same working conditions. To do so, let define $U_{i j}$ as the utility for a work er $i$ in job $j$, which can be expressed as follows:

$U_{i j}=f\left(w_{j}, C_{j} ; X_{i}\right)$,

where $w_{j}$ and $C_{j}$ are the earnings and the working conditions linked to a given job, respectively, and $X_{i}$ a vector of individual characteristics. It is assumed that $U_{w}=\partial U / \partial w>0$, and that for a given working condition $C_{k}$ that if $U_{C}=\partial U / \partial C<0$ then $C_{k}$ is a disamenity, while $C_{k}$ will be an amenity if $U_{C}=\partial U / \partial C \geq 0$. Assume now two types of workers, natives and immigrants, with the following utilities:

$U_{i j m}=f\left(w_{j}, C_{j} ; X_{i m}\right)$ 
$U_{i j n}=f\left(w_{j}, C_{j} ; X_{i n}\right)$,

where the subscripts $m$ and $n$ refer to immigrants and natives, respectively. As we mentioned previously, the precondition for the existence of competition in the labour market between immigrants and natives workers is that both are willing to accept jobs that do not differ in quality. The perception of the quality of a given job for both immigrants and native workers can be easily measured by calculating $U_{C}^{m}=\partial U_{m} / \partial C$ and $U_{C}^{n}=\partial U_{n} / \partial C$. The assumption that immigrants find working conditions acceptable that natives find unacceptable would mean that for a given set of working conditions that $U_{C}^{m} \geq 0$ and $U_{C}^{n}<0$. The latter two conditions would imply the absence of competition. That is, immigrants like, or are at least are indifferent to jobs that natives dislike. On the contrary, if for a given set of working conditions we get $U_{C}^{m} \leq 0$, $U_{C}^{n} \leq 0$ and $U_{C}^{m} \geq 0$, or $U_{C}^{n} \geq 0$ then we can conclude that competition exists, since both natives and immigrants like the same type of jobs. In this situation if immigrant workers with the same skills as their native counterparts are systematically employed in jobs with a larger number of disamenities, then we can conclude that they are discriminated against or that they have fewer opportunities in the labour market.

The utilities expressed in equation (2) can be approached by a satisfaction function $S_{i j}(\bullet)$, for which $S_{i j}(\bullet)>S_{k j}(\bullet)$ if $U_{i j}(\bullet)>U_{k j}(\bullet)$ for $i \neq k$. In this study, we use satisfaction with working conditions as a proxy for the worker's utility.

\section{Data and variables}

The data used in this paper comes from the 2006 Health Survey of Catalonia (Enquesta de Salut de Catalunya 2006 - ESCA2006), which was conducted by the Regional 
Government of Catalonia. The survey contains information on a representative sample of individuals residing in Catalonia at the time of the survey. For the first time, in 2006 the ESCA included a representative sample of immigrants. The share of immigrants in the sample is proportional to number of immigrants residing in Catalonia in 2005. Individuals included in the sample were randomly selected from the population registry of Catalonia. Illegal immigrants are therefore not eligible.

We selected males and females, employed or self-employed, who declared income from labour. The sample consisted of 14,076 adults, of whom $70.47 \%$ were Catalan-born Spaniards (9,919), 21.93\% were non-Catalan-born Spaniards $(3,087)$ and 7.59\% were immigrants $(1,070)$. The composition of the sample of immigrants by birthplace is the following: Latin America (41.59\%), Africa (26.07\%), EU15 and wealthy countries (19.62\%), Central and Eastern Europe (8.41\%) and Asia-Oceania $(4.2 \%)^{2}$

The data provides information regarding individuals and households. At the individual level, because this is a health survey the elicited responses mainly refer to a large set of health-related questions. However, the survey also contains items which provide socio-demographic information such as economic status and employment and, conveniently for the purposes of this study, it includes a large set of questions regarding the working conditions of the respondents.

\subsection{Selected variables}

The socio-demographic variables used in this study are age, gender, marital status, education, household size, area of residence and birth place. The information regarding

\footnotetext{
${ }^{2}$ EU15 refers to the fifteen EU countries before the expansion in 2004, and the wealthy countries group includes the USA, Canada or Australia.
} 
working conditions was based on the following ten questions: 1) Exposure to noise? 2) Exposure to dust? 3) Move heavy loads? 4) Repetitive movements? 5) Monotonous tasks? 6) Work autonomy? 7) Work too much? 8) Poor relationship with colleagues? 9) Poor relationship with superiors? 10) Work alone? Elicited responses are based on a four-point scale. The response scale was: (1) never (2) sometimes (3) often and (4) always. As is common when using this type of information, we have to face the shortcoming that the presence/absence or intensity of a given condition associated with the workplace is self-reported, therefore, these variables are to some extent subjective. We used principal component analysis to collapse these ten self-reported working conditions into four orthogonal factors. The first factor (factor 1) is associated with exposure to noise, dust and moving heavy loads; the second factor (factor 2) refers to the relationship with colleagues and superiors; the third factor (factor 3) refers to monotonous tasks and repetitive movements, and; the fourth factor (factor4) is associated with the degree of autonomy and the possibility of working alone. The variable of whether individuals think they work too much constitutes a unique factor and as such it is taken separately in the regression analysis.

We also considered the risk of injury/death at the workplace as a disamenity. This information is not contained in the ESCA2006. However, we can construct an injury risk indicator using 2006 administrative data from the Ministry of Labour. Our injury risk index is the injury/death rate per 100 employees aggregated into 80 occupation-industry cells (10 occupations and 8 industries).

In addition to the set of self-reported working conditions described above, the survey contains other objective working conditions that, ceteris paribus, are expected to affect workers utility. These are the existence or lack of a labour contract, type of 
contract (indeterminate duration, fixed-term or no contract), working time (morning, afternoon, night or irregular shifts), number of hours worked per week, flexibility in working time, occupational status (salaried or self-employed) and net monthly earnings (in intervals). Additionally, for the sample of immigrants, we also used a variable reflecting whether individuals feel discriminated against in the workplace and the number of years since migration to Spain (YSM). In table 2, we show a description of the selected variables in this analysis.

[Insert table 2 around here]

\subsection{Descriptive statistics}

In table 3 we show summary statistics of the variables used in the analysis. We found remarkable differences by birthplace. The non-Catalan-born Spanish workforce is considerably older than the Catalan-born workforce. Indeed non-Catalan-born workers are, on average, fairly close to retirement age. On the other hand, immigrant workers are much younger than both non-Catalan Spanish and Catalan workers. Immigrants report similar levels of educational attainment as Catalan-born workers (around 11 years of schooling). However, non-Catalan-born Spanish workers are less educated (8.9 years). Separating immigrants by birthplace reveals that Africans are the least educated (8.8 years), while Latin American and EU15 immigrants are in fact more educated than Catalan-born workers (over 12 years). One relevant variable in our analysis is the years since migration (YSM) variable. This variable splits the sample of immigrants into two groups. On the one hand, there are the EU15 workers, who report an average length of stay of over 17.5 years. On the other hand, there are the Latin American and African 
immigrants, who report an average length of stay of approximately 9 and 10 years, respectively.

Average net monthly earnings also reveal significant differences by birthplace. Catalan-born workers and EU15 immigrants report practically the same earnings (around €1,160). Latin American and non-Catalan Spanish workers also report a similar level of earnings (around $€ 1,020$ ), while African-born workers report the lowest level of earnings (around €876). We also observed notable differences in the types of contracts held. Spanish and EU15-born workers report rates of permanent employment of over 55\%, while for African and Latin American workers these rates are 34\% and 40\%, respectively. Finally, the rates of self-employment also display quite different patterns. The highest rate of self-employment is reported by Catalan-born workers, around 22\%, while the lowest rate is observed among African-born workers, around 5\%. NonCatalan-born Spanish, Latin American and EU15-born workers report similar rates of self-employment, between $11 \%$ and $13 \%$.

Remarkable differences were also found among the working conditions considered in the analysis. Recall that our proxy of injury/death risk is based on the rate of injuries/deaths by occupation-industry cells. According to this indicator, on average, African-born workers tend to be employed in riskier jobs, $0.22 \%$, while for the rest of the population groups the average values for this variable ranges from $0.12 \%$ for EU15 to $0.155 \%$ for non-Catalan-born Spanish workers. The same pattern is observed if we consider working time flexibility. With the exception of the African-born workers, there are no significant differences by birthplace. Only 18.5\% of African-born workers report enjoying flexible work hours, while for the rest of groups this percentage ranges between 39.6 and $47.1 \%$ for EU15 and Catalan-born workers, respectively. 
Recall that we cluster nine of the working conditions into four orthogonal factors using principal component analysis. These factors were used in the regression analysis; however, for the descriptive analysis we used each working condition separately as they were elicited in the survey. For the working conditions associated with factor 1 (exposure to dust, noise and move heavy loads), we found that Catalan-born workers report the lowest exposure to these on-the-job disamenities, while African-born workers report the highest exposure to these working conditions. There were not significant differences by birthplace with regard to the existence of a poor relationship with colleagues and superiors (factor 2). On average, Catalan and EU15 born workers are less likely than immigrants and non-Catalan-born Spanish workers to be engaged in jobs that involve monotonous tasks and repetitive movements (factor 3). African-born workers report the lowest levels of autonomy in their jobs (factor 4), while no differences among the rest of the population groups were observed. Our discrimination indicator revealed that almost $20 \%$ of the immigrant workers report experiencing discrimination in the workplace. By birthplace, the African-born workers are the most discriminated against (32.2\%), followed by Latin Americans (16.6\%), other (15.5\%) and EU15 (11.4\%).

Finally, we also found some differences in the level of satisfaction with working conditions by birthplace. EU15 and Catalan-born workers are the most satisfied, 3.16 and 3.11, respectively, followed by non-Catalan Spanish (3.01), Latin American (2.95) and African-born workers (2.88).

[Insert table 3 around here] 
Table 4 shows the results of the t-tests on the differences in average satisfaction by birthplace. No statistically significant differences were found between Catalan-born Spanish and EU15 workers. The same conclusions were drawn when comparing Latin American with African and non-Catalan-born Spanish workers. However, statistically significant differences in average satisfaction are observed if we compare Latin American with Catalan-born and EU15 workers; African with Spanish (non-Catalanand Catalan-born) and EU15 workers, and; non-Catalan Spanish with Catalan-born Spanish and EU15 workers.

[Insert table 4 around here]

\section{Empirical strategy and results}

\subsection{Identifying workplace (dis)amenities}

One important issue is determining which of the working conditions described in the previous section are perceived as (dis)amenities by workers. As discussed in section 3, we assume that a given working condition is perceived as a disamenity if it exerts a negative effect on a worker's utility. We followed the conceptual framework described in section 3. Hence, we assume that the propensity of an individual $i$ to report a certain level of satisfaction (utility) is driven by the following linear relationship:

$$
S_{i}^{*}=\alpha+\delta w_{i}+\sum_{k} \beta_{k} C_{k}+\sum_{m} \gamma_{m} X_{m}+e_{i}
$$

where $S_{i}^{*}$ is a latent outcome regarding the worker's satisfaction and $e_{i}$ is a random error term. We consider that a given working condition $\mathrm{C}_{k}$ is considered as a disamenity if in the linear relationship expressed in (3), we get that $\beta_{k}<0$. We do not observe $S_{i}^{*}$ but 
instead an indicator variable of the type $S_{i}=j$ if $\mu_{j-1}<S_{i}^{*} \leq \mu_{j}(j=1, \ldots, J)$. According to this observability rule, if we assume that $e_{i}$ is normally distributed, then equation (3) can be estimated by means of the conventional ordered probit model. However, we prefer the approach proposed in Van Praag and Ferrer-i-Carbonell (2006). Their approach, called the POLS (Probit OLS) model, involves the transformation of the response variable $S_{i}=j$ to $\ln \left(z_{j}\right)$ as follows:

$\ln \left(z_{j}\right)=\frac{\phi\left(\mu_{j-1}\right)-\phi\left(\mu_{j}\right)}{\Phi\left(\mu_{j}\right)-\Phi\left(\mu_{j-1}\right)}$

where $\phi(\bullet)$ and $\Phi(\bullet)$ are the normal density function and the cumulative normal distribution, respectively. This reformulation eliminates the need to calculate marginal effects in an ordinal probit framework, which is a bit cumbersome. Under the POLS approach, equation (3) becomes:

$\ln \left(z_{i}\right)=\alpha+\delta \ln \left(w_{i}\right)+\sum_{k} \beta_{k} \ln \left(C_{k}\right)+\sum_{m} \gamma_{m} X_{m}+\varepsilon_{i}$

Equation (5) provides a straightforward interpretation of the estimated effects across alternative models. Van Praag and Ferrer-i-Carbonell (2006), show that differences in the estimated parameters between the POLS and the ordered probit model are due to a multiplication factor. ${ }^{3}$

\subsection{Estimates of job satisfaction equations}

Table 5 reports the results of the estimates of equation (5). We carried out separate estimates for Catalan Spanish, non-Catalan Spanish and non-Spanish workers. We

\footnotetext{
${ }^{3}$ See van Praag and Ferrer-i-Carbonell (2006) for further details.
} 
found that the individual characteristics that determine job satisfaction differ among groups of workers according to birthplace. For the Spanish-born workers (Catalan and non-Catalan) education does not affect job satisfaction. However, for immigrants this effect is negative and statistically significant. This result, combined with the fact that immigrants are not, on average, less educated than natives, may suggest that most immigrants are overeducated in relation to their jobs. As expected, we found that job satisfaction is U-shaped on age for Catalan-born workers; however it was not statistically significant for non-Catalan Spanish and immigrant workers. This result might indicate low job mobility, at least in terms of job quality, for non-Catalan-born workers. We also observed that gender is not significant in any of the population groups. This result we obtained for Catalonia does not coincide with the common result that women tend to display greater job satisfaction than men (e.g. Diaz-Serrano and Vieira, 2006).

One relevant result concerns the effect of the years since migration (YSM) variable for immigrant workers. Surprisingly, this variable does not exert a statistically significant effect on job satisfaction. To test the possibility of a differential effect of this variable by birthplace among immigrants, we also experimented with the interactions of the YSM variable with dummies for birthplace, but they turned out to be statistically insignificant. ${ }^{4}$ This result is comparable to the effect of age for non-Catalan-born Spanish immigrants, since in both cases it suggests that satisfaction with the working conditions in the Catalan job market do not improve over time for these population groups. In the immigrants' satisfaction equation, we also include a proxy for “perceived on-the-job discrimination”. This variable is a four-point ordinal scale. We transform this

\footnotetext{
${ }^{4}$ The results of the interaction terms between years of residence and origin are not included in table 4 .
} 
variable into a binary indicator that takes the value of one if the immigrant worker answers that he(she) feels discriminated against at work (constantly, often or sometimes) and zero if the worker declares that he(she) or she has never felt discriminated against. The effect of this variable proved statistically significant and negative. Our results indicate that for those who feel discriminated against at work, satisfaction with their working conditions decreases to around 14.4 percent.

The results on the effect of particular working conditions on job satisfaction are reported in table 4 and are quite revealing. While job amenities tend to have the expected effect in all population groups, we find some striking differences in the case of job disamenities. Job satisfaction is negatively affected by the existence of poor environmental conditions (factor 1) for Spanish workers (Catalan and non-Catalan), while it is not for immigrants. Poor relations with superiors and colleagues (factor 2) and the execution of tedious tasks (factor 3) exert a significant negative effect on satisfaction in all population groups. This effect is statistically significant and similar in magnitude by birth place, though the effect of factor 3 is remarkably stronger that the effect of factor 2. Autonomy in the workplace (factor 4) exerts a positive and statistically significant effect on workers' satisfaction only for the Spanish-born workers (Catalan and non-Catalan), while enjoying flexible working hours positively affects job satisfaction for all workers. This effect is similar in magnitude in all population groups. The feeling of working too much also generates disutility to all groups of workers. The effect is remarkably larger for the sample of immigrants than for Spanish-born workers. Surprisingly, being employed in a job with high risk of injury causes dissatisfaction to Spanish-born workers, but does not to immigrants. This result is quite revealing, since it 
suggests that immigrants either have a different perception of risk or are more risktolerant. $^{5}$

Contract type and the working times also proved significant in determining job satisfaction. Not having a permanent/indefinite contract (fixed-term or no contract) exerts a negative effect on job satisfaction similar in magnitude for both Spanish and immigrant workers. Working at night generates dissatisfaction in all workers, while working with irregular or changing shifts only (negatively) affects job satisfaction for Spanish-born workers. The negative effect of working at night on workers' utility is remarkably larger for immigrants than for Spanish-born workers. Finally, regarding location dummies, we observe that workers located in the area of Barcelona city report lower job satisfaction than those located in the rest of Catalonia.

The results obtained in this section allow us to conclude that immigrant workers and native-born workers may perceive some working conditions differently. That is, immigrants may accept some working conditions that natives find unacceptable. For instance, the risk of injury, the exposure to poor environmental working conditions, a lack of autonomy in the workplace, not having a permanent contract and working at irregular times or changing shifts exert a negative effect on native workers' utility, whereas they are not statistically significant in the estimates of immigrant workers' satisfaction equations. This result may suggest that if competition between immigrants and Spanish-born workers exists, this is limited.

[Insert table 5 around here]

\footnotetext{
${ }^{5}$ For immigrants, we also interacted working conditions with birthplace and we did not find any statistically significant differences.
} 


\subsection{Estimates of working conditions equations}

In this section we examine whether on-the-job amenity packages received by natives differ from those received by their immigrant counterparts, and whether there is a catchup process for immigrants in terms of job quality compared to natives. That is, we extend the conventional immigrant assimilation analysis to immigrants' working conditions. In section 3.2 (table 2), we described a separate descriptive analysis by birthplace of individual working conditions, however, the package of on-the-job (dis)amenities is mostly inherent in one's choice of labour supply, which in turn depends on socio-demographic and economic factors, among other things. Therefore, in order to test whether immigrants and natives enjoy different working conditions, we had to control for the set of workers' demographic characteristics. We did this by estimating the probability of enjoying/suffering a given good/bad working condition holding age, education, marital status and family size constant. Additionally, we conducted a separate analysis for immigrants and included as a covariate the years since migration to Spain (YSM) variable, which allowed us to test for immigrant assimilation in terms of job quality.

We did separate estimates for Catalan-born, non-Catalan-born Spanish and nonSpanish-born workers. ${ }^{6}$ Recall that according to the results reported by the estimates of the satisfaction equations, we consider on-the-job disamenities to be the following working conditions: fixed-term contract, working without contract, working in an occupation-industry with higher risk of injury/accident, working at night or with irregular shifts, poor environmental conditions (factor 1), poor relations with colleagues and superiors (factor 2), repetitive and monotonous tasks (factor 3) and working too

\footnotetext{
${ }^{6}$ For the full sample we only show the estimated effect for the birthplace dummies, however, full estimates are available from the author upon request.
} 
much. Additionally, for immigrants we also considered the perception of being discriminated against in the workplace as a disamenity. Following the same criteria, we assume as amenities: having a permanent or indeterminate duration contract, working the morning or morning/afternoon shift, enjoying flexible working times and autonomy in the workplace (factor 4). We used the conventional probit model when the outcome variable was binary and the linear regression model otherwise. In the separate equations for immigrants, we also included the variable of whether the worker feels discriminated against in the workplace as a covariate. We include this variable in order to control for the extent to which immigrants who feel discriminated against might exaggerate the level of disamenities they suffer in the workplace (Hamermesh, 1978). This misperception of the working conditions might introduce some bias in the measurement of our outcome variable, and hence, also potentially bias the estimated effects of the covariates.

In tables A1 to A5 in the annex, we report the results of the estimates of the probit and linear regression models using the working condition determinants mentioned above. In order to allow for comparisons across alternative models, for the probit models we report estimated marginal effects instead of estimated coefficients. Statistical significance was assessed at 5\%.

\subsubsection{Differences in working conditions by birthplace ${ }^{7}$}

Once we controlled for socio-economic factors, we found that non-Catalan-born Spanish workers tend to experience worse working conditions than their similar Catalan-born counterparts. More specifically, this group of workers is more likely: to

\footnotetext{
${ }^{7}$ Birthplace dummies are presented in table A1-A5 in the column labelled as Catalan, however, the estimated coefficients regarding these dummies are estimated using the full sample.
} 
work without a contract (1.1\%), to enjoy less flexibility and autonomy in the workplace (-9.6\%), to be exposed to worse environmental conditions (9.9\%) and to perform more monotonous tasks than Catalan-born workers (14.8\%). ${ }^{8}$ Comparing now Catalan-born workers with non-Spanish-born workers, we observe that the working conditions of EU15-born workers do not differ significantly from those of Catalan-born workers. This result indicates that EU15 immigrants are employed in more highly skilled jobs than other groups of immigrants, and that this group of workers are in direct competition with Catalan-born workers for the same type of jobs. Surprisingly, we also found that Latin American-born workers enjoy better working conditions than non-Catalan-born Spanish workers in some aspects such as flexibility in working times (-9.2 vs. 4.4\%, respectively), poor environmental conditions ( 0 vs. 9.9\%) and autonomy in the workplace (0 vs. 10.9\%). Meanwhile, in other aspects such as holding a permanent contract (-20.1 vs. 5.5\%), working without a contract (6 vs. 1.1\%) and performing monotonous tasks in the workplace (26.6 vs. $14.8 \%$ ), Latin American immigrants report worse working conditions than non-Catalan Spaniards. Comparing Latin American workers with their Catalan and EU15-born counterparts, we find that Latin American immigrants suffer worse working conditions in only two aspects (permanent contract and monotonous tasks), whereas non-Catalan-born Spanish workers experience more negative working conditions than their Catalan counterparts in five different aspects. In order to test whether recent Latin American immigrants differ from their earlier counterparts, we interacted the dummy variable for Latin America with dummy variables for years since migration. ${ }^{9}$ We did this for working conditions that did not significantly differ between Latin American and Catalan-born workers, i.e. risk of

\footnotetext{
${ }^{8}$ All the percentages mentioned in section 4.3 .1 are the estimated marginal effects for the birthplace dummies in the working conditions equations taking as base category the Catalan-born workers.

${ }^{9}$ These results are not reported but are available from the author upon request.
} 
injury, flexibility in working times, poor environmental conditions, autonomy in the workplace and working too much. This analysis showed that neither early nor recent Latin American immigrants differ from native Catalan-born workers in their adjusted propensities in the working conditions mentioned above.

African-born workers suffer the worst working conditions in practically all the aspects studied. For instance, this group of workers is the only one that, after controlling for socio-demographic characteristics, still reports statistically significant differences in the risk of injury/death variable (16.4\%) compared to other groups of workers, whether natives or not. Estimated coefficients for African-born dummies are always larger than for native and non-native workers, though regarding contractual conditions, African and Latin American-born workers are in a similar situation. Differences in working conditions are especially important for flexibility in working times, risk of injury, poor environmental conditions, poor relations with colleagues/superiors and autonomy in the workplace.

\subsubsection{The effect of socio-demographic variables}

This section describes the estimated coefficients for socio-demographic variables. We obtained the expected result that better educated workers enjoy better working conditions, i.e. we estimated a positive sign for the set of amenities and negative for disamenities. The only exceptions to this general result were: poor relations in the work place for non-Catalan-born workers, autonomy in the work place for Catalan-born workers and working too much for non-Catalan-born Spanish workers. Age is statistically significant in all (dis)amenities only for Catalan-born workers. This effect tends to be U-shaped for the set of amenities and inverted U-shaped or linear 
negative for the set of disamenities. For non-Catalan-born Spanish workers, age exerts a statistically significant and linear effect only for contract type (permanent and without contract) and autonomy in the workplace. For immigrants, age is even more irrelevant, as this variable was found to be statistically significant only for the factor associated with poor relationships with colleagues. This effect is inverted U-shaped. Women are more likely to work without a contract, in less risky occupation-industries, with better environmental conditions, and in jobs that involve more monotonous tasks. Regarding the effect of household size and marital status, we found that these variables do not exert a significant effect in determining individuals' working conditions for any population group.

\subsubsection{Assimilation and discrimination}

For immigrant workers, the variable reflecting the extent to which they feel discriminated against was found to be statistically significant only in some of the working condition equations. This variable tends to exert a statistically significant effect mostly on self-reported working conditions, which confirms the notion mentioned previously that workers who feel discriminated against may exaggerate the extent to which they are exposed to job disamenities. In our case, immigrant workers who feel discriminated against in the workplace are less likely to have a permanent contract, more likely to report poor relations with superiors and colleagues and claim to work too much. If we set statistical significance at $10 \%$, discrimination also becomes significant in the equation regarding poor environmental conditions.

Our results also indicate that there is a certain degree of assimilation of immigrant workers in terms of job quality. The number of years since migration to 
Spain (YSM) increases the probability of having a permanent contract, enjoying flexibility in working times and autonomy in the workplace, whereas it reduces the probability of performing monotonous tasks in the workplace, working without a contract and feeling discriminated against in the workplace. The variable YSM does not exert a statistically significant effect on the probability of working in a risky occupation-industry, while the effect of experiencing poor environmental conditions and the feeling of working too much is inverted U-shaped. That is, these variables increase with YSM but at a decreasing rate. We found the two former results might indicate that while immigrants may improve their legal (type of contract) and emotional (relationships) working conditions with YSM, they may experience low job mobility. That is, immigrant workers employed in low-skilled jobs in construction or agriculture may experience difficulties in moving to better jobs.

\section{Summary and concluding remarks}

The claim that immigrants take jobs away from natives is one of the main arguments against immigration. And, not surprisingly, this claim becomes even stronger in periods of higher unemployment. The conventional approach to analysing the effect of immigration on natives' labour outcomes has mainly focused on: i) measuring the degree of substitution between natives and immigrants, and; ii) the effect of immigration on native earnings. As did Hammermesh (1998), we have taken an alternative approach and tested whether the preconditions for direct competition between natives and immigrants exist. That is, we tested whether: i) immigrants display a preference for the same type of jobs as natives, and; ii) immigrants accept jobs, in terms of quality, that natives tend to refuse. Our results are quite revealing: we found 
that the taste for job (dis)amenities between natives and immigrants may differ, or at least they have a different perception of the same (dis)amenities. Having a permanent contract, working at irregular times or changing shifts, working in jobs with a higher risk of injury, higher exposure to poor environmental conditions and lower degree of autonomy do not exert a significant effect on immigrants' job satisfaction, whereas they do on natives' satisfaction. Only non-Catalan Spaniards have shown indifference to working at night and in jobs with a higher risk of injury.

Given these differences, one may think that immigrants are likely to find some jobs acceptable that natives would find unacceptable, at least in the early years after their arrival in Spain. Natives tend to enjoy better contractual conditions than immigrants, though this situation tends to improve with years since migration to Spain. Regarding the remaining working conditions, we found that EU15 and Catalan-born workers are employed in jobs with the same amenities, which suggest that they are direct competitors in the Catalan labour market. On the other hand, African-born immigrants suffer the worst working conditions of all the groups of workers. This situation may be caused by the fact that they are mainly employed in construction and agriculture. It is interesting that non-Catalan Spaniards face worse working conditions than their Catalan-born counterparts. However, the set of on-the-job amenities experienced by non-Catalan Spaniards and Latin Americans are fairly similar, what also suggests that they might compete, at least partially, in the Catalan labour market. These results indicate that there is a degree of competition between natives and immigrants, but it is limited. Our estimates suggest that competition for high-skilled jobs exists between Catalan and EU15 workers, while Latin American and non-Catalan natives might compete for lower-skilled jobs. Finally, African-born workers do not seem to be 
in competition with other groups of workers, since they tend to take jobs that native, especially Catalan, and even other groups of immigrants are unwilling to take. 


\section{References}

Altonji, J.G. y D. Card (1991), "The Effects of Immigration on the Labor Market Outcomes of Less-Skilled Natives.” In Immigration, Trade and Labor, edited by John M. Abowd, and Richard B. Freeman. Chicago: University of Chicago Press.

Basu, A. (1998), “An Exploration of Entrepreneurial Activity among Asian Small Businesses in Britain,” Small Business Economics 10 (4), 313-326.

Borjas, G.J. (1986), "The Self-Employment Experience of Immigrants”, Journal of Human Resources 21 (4), 485-506.

Borjas, G.J. (2003), “The Labor Demand Curve Is Downward Sloping: Reexamining the Impact of Immigration on the Labor Market.” Quarterly Journal of Economics, 118(4), pp.1335-1374.

Borjas, GJ (1999) Heaven's door: immigration policy and the American economy. Princeton University Press, New Jersey.

Borjas, George J.; Grogger, Jeffrey; Hanson, Gordon H. (2008), Imperfect Substitution between Immigrants and Natives: A Reappraisal. National Bureau of Economic Research, Inc, NBER Working Papers: 13887.

Bover, O. and P. Velilla, 2002. "Migrations in Spain: Historical Background and Current Trends," in K. Zimmermann (ed.), European Migration: What Do We Know? CEPR and Oxford University Press.

Card, D. (2001), "Immigrant Inflows, Native Outflows, and the Local Labor Market Impacts of Higher Immigration.” Journal of Labor Economics, 19(1), pp. 22-64.

Clark, K. and S. Drinkwater (1998), “Ethnicity and Self-employment in Britain”, Oxford Bulletin of Economics and Statistics 60 (3), 383-407. 
Fairlie, R.W. and B.D. Meyer (1996), "Ethnic and Racial Self-employmentDifferences and Possible Explanations”, Journal of Human Resources 31 (4), 757-793.

Friedberg RM, Hunt J (1995) The impact of immigrants on host country wages, employment and growth. Journal of Economic Perspectives, 9(2):23-44

Gazioglu, S. and Sloan P.J. (1994) Job Disamenities, Compensating Differentials and the Immigrant Workers, International Journal of Manpower 15(7): 44-52.

Gang, Ira N.; Rivera-Batiz, Francisco L. (1994), “Labor Market Effects of Immigration in the United States and Europe: Substitution vs. Complementarity”, Journal of Population Economics 7(2), 157-75.

Hamermesh, D.S. (1978), Economic aspects of job satisfaction, in Ashenfelter, O. and Oates, W. eds., Essays in Labour Market Analysis. John Wiley and Sons, New York, pp. 53-72.

Hamermesh, D.S. (1998), Immigration and the Quality of Jobs”, in D. Hamermesh and F. Bean, eds., Help or hindrance? The economic implications of immigration for African Americans. Russell Sage Foundation, New York, pp. 75-106.

LaLonde, R. and R. Topel (1991), “Labor Market Adjustments to Increased Immigration.” In Immigration, Trade and Labor, edited by John M. Abowd, and Richard B. Freeman. Chicago: University of Chicago Press.

Ottaviano, Gianmarco I. P.; Peri, Giovanni (2005), Rethinking the Gains from Immigration: Theory and Evidence from the U.S., National Bureau of Economic Research, Inc, NBER Working Papers: 11672

Ottaviano, Gianmarco I. P.; Peri, Giovanni (2008), Immigration and National Wages: Clarifying the Theory and the Empirics 
Pischke JS, Velling J (1997) Employment effects of immigration to Germany: an analysis based on local labour markets. The Review of Economics and Statistics, 79:594-604.

Zorlu, A. and J. Hartog (2005), “The Effect of Immigration on Wages in Three European Countries”, Journal of Population Economics 18(1), 113-51. 
Table 1: Distribution of employment by occupation and industry by birth of place

\begin{tabular}{|c|c|c|c|c|c|c|c|c|}
\hline & & \multicolumn{2}{|r|}{ Spanish } & \multicolumn{5}{|c|}{ Non-Spanish } \\
\hline & & $\begin{array}{c}\text { Non } \\
\text { Catalan }\end{array}$ & Catalan & African & $\begin{array}{r}\text { Latin } \\
\text { American }\end{array}$ & EU15 & $\begin{array}{r}\text { East } \\
\text { Europe }\end{array}$ & Asia \\
\hline \multirow[t]{8}{*}{ Occupations } & Managers & 8.74 & 12.59 & 2.22 & 3.94 & 18.56 & 8.00 & 12.92 \\
\hline & Professionals & 8.71 & 15.27 & 1.66 & 7.63 & 24.74 & 15.88 & 5.63 \\
\hline & Technicians & 8.87 & 13.75 & 1.94 & 7.19 & 16.00 & 7.06 & 7.71 \\
\hline & Clerical & 6.98 & 9.92 & 2.72 & 7.04 & 5.72 & 3.41 & 3.75 \\
\hline & Restoration, services and commerce & 12.76 & 11.48 & 9.32 & 20.31 & 9.30 & 14.59 & 25.31 \\
\hline & White-collar & 12.55 & 10.99 & 12.83 & 6.71 & 5.63 & 12.00 & 4.06 \\
\hline & Operators & 16.51 & 11.04 & 11.19 & 8.33 & 7.21 & 12.59 & 11.35 \\
\hline & Blue-collar & 24.87 & 14.97 & 58.11 & 38.85 & 12.84 & 26.47 & 29.27 \\
\hline \multirow[t]{9}{*}{ Industry } & Agriculture \& fishing & 1.46 & 4.04 & 13.88 & 0.97 & 1.72 & 10.82 & 3.65 \\
\hline & Mining & 0.06 & 0.09 & & 0.12 & 0.14 & & \\
\hline & Manufacturing & 27.57 & 23.35 & 21.54 & 14.92 & 20.65 & 19.76 & 19.27 \\
\hline & Construction & 15.58 & 10.23 & 35.50 & 15.37 & 8.56 & 16.71 & 8.23 \\
\hline & Hostelry and commerce & 18.54 & 20.06 & 15.87 & 24.02 & 21.12 & 18.00 & 39.17 \\
\hline & Transport, communications and finance & 10.29 & 10.57 & 2.18 & 6.49 & 10.93 & 8.94 & 10.00 \\
\hline & Real estate and corporate services & 11.87 & 14.27 & 3.54 & 9.40 & 15.12 & 9.65 & 3.75 \\
\hline & Education \& health & 9.49 & 13.46 & 1.83 & 8.28 & 16.42 & 8.47 & 6.35 \\
\hline & Other services & 5.13 & 3.92 & 5.67 & 20.43 & 5.35 & 7.65 & 9.58 \\
\hline
\end{tabular}


Table 2: Description of the variables

\begin{tabular}{|c|c|}
\hline Variable & Description \\
\hline \multicolumn{2}{|l|}{ Demographic characteristics } \\
\hline \multicolumn{2}{|l|}{ Age } \\
\hline \multicolumn{2}{|l|}{ Gender } \\
\hline \multicolumn{2}{|l|}{ Years of schooling } \\
\hline Married & Dummy variable takes the value 1 if the individual is married \\
\hline Children & Number of individuals younger than 14 years old living in the household \\
\hline Years since migration (YSM) & Years since the individual arrived in Spain \\
\hline \multicolumn{2}{|l|}{ Birth place } \\
\hline Catalan & Dummy variable takes the value 1 if the individual was born in Catalonia \\
\hline & Dummy variable takes the value 1 if the individual was born in Spain outside of \\
\hline Non-Catalan Spanish & Catalonia \\
\hline African & Dummy variable takes the value 1 if the individual was born in Africa \\
\hline Latin American & Dummy variable takes the value 1 if the individual was born in Latin America \\
\hline EU15 & $\begin{array}{l}\text { Dummy variable takes the value } 1 \text { if the individual was born in one of the } 15 \text { countries } \\
\text { of the EU before the enlargement of 2004; wealthy countries such as Canada, } \\
\text { USA or Australia are also considered in this group }\end{array}$ \\
\hline Other & $\begin{array}{l}\text { Dummy variable takes the value } 1 \text { if the individual was born in Asia, Oceania, Central } \\
\text { or Eastern Europe }\end{array}$ \\
\hline
\end{tabular}

Objective working conditions

Weekly hours

Number of hours worked per week

Net monthly earnings

Individual net monthly earnings intervals

Working times

FT Intensive morning; FT Intensive afternoon/evening; FT Intensive night; FT

Changing shift; FT Irregular/variable shifts; Part-time; Other

Type of contract

Risk of injury/death

Permanent; Indeterminate duration; Fixed-term; Self-employed; No contract; Other

Percentage of workers that suffered an injury or death of all workers in each occupation-education cell (see table 1 for occupations and industries).

\section{Subjective working conditions}

Flexible working times

Flexibility in working times? (Yes/No)

Working too much

Noise

Dust

Work too much? (1. Never; 2. Sometimes; 3. Often; 4. Always)

Exposure to noise? (1. Never; 2. Sometimes; 3. Often; 4. Always)

Heavy

Exposure to dust? (1. Never; 2. Sometimes; 3. Often; 4. Always)

Move heavy loads? (1. Never; 2. Sometimes; 3. Often; 4. Always)

Work tasks involve repetitive movements? (1. Never; 2. Sometimes; 3. Often; 4.

Repetitive

Monotonous

Always)

Autonomy

Alone

Work involves monotonous tasks? (1. Never; 2. Sometimes; 3. Often; 4. Always)

Autonomy in the work place? (1. Never; 2. Sometimes; 3. Often; 4. Always)

Colleagues

Work task involves working alone? (1. Never; 2. Sometimes; 3. Often; 4. Always)

Superiors

Discrimination

Poor relationship with colleagues? (1. Never; 2. Sometimes; 3. Often; 4. Always)

Poor relationship with superiors? (1. Never; 2. Sometimes; 3. Often; 4. Always)

Only for immigrants. Do you feel discriminated against at work? (1. Never; 2.

Sometimes; 3. Often; 4. Always)

Job Satisfaction

Satisfaction with the working conditions? (1. Very dissatisfied; 2. Dissatisfied; 3. Satisfied; 4. Very satisfied)

Note: FT - Full time 
Table 3: Summary statistics

\begin{tabular}{|c|c|c|c|c|c|c|c|c|}
\hline & \multicolumn{4}{|r|}{ Spanish } & \multicolumn{2}{|c|}{ Immigrant } & \multicolumn{2}{|c|}{ Full sample } \\
\hline & \multicolumn{2}{|c|}{ Catalan-born } & \multicolumn{2}{|c|}{ Non Catalan-born } & \multicolumn{2}{|c|}{ Non Spanish-born } & & \\
\hline & Mean & S.D. & Mean & S.D. & Mean & S.D. & Mean & S.D. \\
\hline \multicolumn{9}{|l|}{ Individual characteristics } \\
\hline Age & 45.402 & 18.623 & 57.389 & 15.346 & 37.848 & 13.331 & 47.457 & 18.470 \\
\hline Years of schooling & 11.105 & 3.373 & 8.900 & 3.686 & 11.320 & 3.796 & 10.638 & 3.598 \\
\hline Women & 0.474 & 0.499 & 0.477 & 0.500 & 0.428 & 0.495 & 0.471 & 0.499 \\
\hline Household size & 3.062 & 1.203 & 2.853 & 1.139 & 3.552 & 1.585 & 3.054 & 1.234 \\
\hline Years living in Spain & & & & & 11.432 & 13.586 & 11.432 & 13.586 \\
\hline \multicolumn{9}{|l|}{ Job characteristics } \\
\hline Monthly net earnings $(€)^{1}$ & $1,168.96$ & 780.09 & $1,039.21$ & 663.28 & $1,015.88$ & 617.59 & $1,127.98$ & 746.24 \\
\hline Weekly hours worked & 40.729 & 10.180 & 40.657 & 8.981 & 40.485 & 10.718 & 40.695 & 9.981 \\
\hline Permanent contract & 0.590 & 0.492 & 0.672 & 0.470 & 0.438 & 0.496 & 0.596 & 0.491 \\
\hline Fixed-term contract & 0.151 & 0.358 & 0.113 & 0.316 & 0.374 & 0.484 & 0.160 & 0.366 \\
\hline Without contract & 0.035 & 0.183 & 0.076 & 0.266 & 0.084 & 0.278 & 0.048 & 0.213 \\
\hline Self-employed & 0.220 & 0.415 & 0.135 & 0.342 & 0.103 & 0.304 & 0.193 & 0.395 \\
\hline \multicolumn{9}{|l|}{ Working conditions } \\
\hline Flexible working times & 0.471 & 0.499 & 0.388 & 0.487 & 0.355 & 0.479 & 0.446 & 0.497 \\
\hline Risk of injury & 0.154 & 0.189 & 0.155 & 0.160 & 0.157 & 0.172 & 0.155 & 0.182 \\
\hline Work too much ${ }^{2}$ & 2.223 & 1.015 & 2.320 & 1.079 & 2.215 & 1.013 & 2.238 & 1.026 \\
\hline \multicolumn{9}{|l|}{ Factor 1} \\
\hline Exposure to noise $^{2}$ & 1.604 & 0.900 & 1.757 & 0.997 & 1.736 & 1.001 & 1.642 & 0.928 \\
\hline Exposure to dust ${ }^{2}$ & 1.598 & 0.973 & 1.767 & 1.069 & 1.796 & 1.077 & 1.644 & 1.002 \\
\hline Move heavy loads ${ }^{2}$ & 1.599 & 0.929 & 1.698 & 0.982 & 1.754 & 1.014 & 1.630 & 0.948 \\
\hline \multicolumn{9}{|l|}{ Factor 2} \\
\hline Poor relationship with colleagues ${ }^{2}$ & 2.317 & 1.184 & 2.576 & 1.193 & 2.489 & 1.178 & 2.375 & 1.189 \\
\hline Poor relationship with superiors ${ }^{2}$ & 1.925 & 1.094 & 2.226 & 1.208 & 2.252 & 1.133 & 2.005 & 1.125 \\
\hline \multicolumn{9}{|l|}{ Factor 3} \\
\hline Repetitive movements ${ }^{2}$ & 2.028 & 1.129 & 2.049 & 1.171 & 2.002 & 1.138 & 2.029 & 1.137 \\
\hline Monotonous tasks ${ }^{2}$ & 2.872 & 1.139 & 2.797 & 1.176 & 2.452 & 1.205 & 2.820 & 1.158 \\
\hline \multicolumn{9}{|l|}{ Factor 4} \\
\hline$\overline{\text { Work alone }^{2}}$ & 1.100 & 0.438 & 1.129 & 0.507 & 1.136 & 0.501 & 1.108 & 0.456 \\
\hline Work autonomy ${ }^{2}$ & 1.115 & 0.447 & 1.130 & 0.494 & 1.146 & 0.524 & 1.120 & 0.463 \\
\hline Discrimination & & & & & 0.195 & 0.239 & & \\
\hline Satisfaction working conditions ${ }^{3}$ & 3.111 & 0.620 & 3.016 & 0.615 & 3.004 & 0.680 & 3.085 & 0.626 \\
\hline
\end{tabular}

Notes: (1) This variable is in intervals. We considered the wage to be the middle point of the salary interval reported by the respondent.

(2) The codes for the variable are: 1. Never; 2. Sometimes; 3. Often; 4. Always

(3) The codes for the variable are: 1 . Very dissatisfied; 2. Dissatisfied; 3. Satisfied; 4. Very satisfied 
Table 3 (Continuation)

\begin{tabular}{|c|c|c|c|c|c|c|c|c|}
\hline & \multicolumn{2}{|r|}{ African } & \multicolumn{2}{|c|}{ Latin American } & \multicolumn{2}{|c|}{ European Union } & \multicolumn{2}{|c|}{ Other origin } \\
\hline & Mean & S.D. & Mean & S.D. & Mean & S.D. & Mean & S.D. \\
\hline \multicolumn{9}{|l|}{ Individual characteristics } \\
\hline Age & 35.498 & 11.291 & 37.357 & 12.440 & 41.292 & 16.182 & 36.291 & 10.765 \\
\hline Years of schooling & 8.824 & 4.162 & 12.427 & 3.158 & 12.045 & 3.316 & 11.036 & 3.226 \\
\hline Women & 0.258 & 0.438 & 0.499 & 0.501 & 0.498 & 0.501 & 0.345 & 0.480 \\
\hline Household size & 3.928 & 1.818 & 3.578 & 1.503 & 3.024 & 1.293 & 4.182 & 1.611 \\
\hline Years living in Spain & 9.781 & 9.428 & 8.833 & 11.609 & 17.679 & 18.105 & 7.818 & 5.941 \\
\hline \multicolumn{9}{|l|}{ Job characteristics } \\
\hline 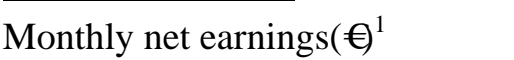 & 876.75 & 393.03 & $1,019.74$ & 566.20 & $1,161.22$ & 835.51 & 925.00 & 454.27 \\
\hline Weekly hours worked & 40.249 & 10.128 & 40.452 & 11.645 & 40.689 & 9.395 & 40.857 & 11.946 \\
\hline Permanent contract & 0.344 & 0.476 & 0.409 & 0.492 & 0.567 & 0.496 & 0.473 & 0.504 \\
\hline Fixed-term contract & 0.509 & 0.501 & 0.389 & 0.488 & 0.237 & 0.426 & 0.291 & 0.458 \\
\hline Without contract & 0.097 & 0.296 & 0.090 & 0.286 & 0.069 & 0.253 & 0.055 & 0.229 \\
\hline Self-employed & 0.050 & 0.219 & 0.110 & 0.313 & 0.127 & 0.334 & 0.182 & 0.389 \\
\hline \multicolumn{9}{|l|}{ Working conditions } \\
\hline Flexible working times & 0.185 & 0.389 & 0.429 & 0.496 & 0.396 & 0.490 & 0.383 & 0.491 \\
\hline Risk of injury & 0.228 & 0.199 & 0.129 & 0.154 & 0.124 & 0.145 & 0.159 & 0.171 \\
\hline Work too much ${ }^{2}$ & 2.439 & 1.003 & 2.196 & 1.007 & 2.101 & 1.022 & 1.833 & 0.853 \\
\hline \multicolumn{9}{|l|}{ Factor 1} \\
\hline Exposure to noise $^{2}$ & 1.976 & 1.055 & 1.587 & 0.921 & 1.779 & 1.044 & 1.571 & 0.914 \\
\hline Exposure to dust ${ }^{2}$ & 2.094 & 1.127 & 1.712 & 1.047 & 1.668 & 1.041 & 1.667 & 1.004 \\
\hline Move heavy loads ${ }^{2}$ & 2.212 & 1.065 & 1.578 & 0.940 & 1.645 & 0.985 & 1.500 & 0.804 \\
\hline \multicolumn{9}{|l|}{ Factor 2} \\
\hline Poor relation colleagues ${ }^{2}$ & 1.179 & 0.628 & 1.101 & 0.368 & 1.120 & 0.466 & 1.310 & 0.811 \\
\hline Poor relation superiors ${ }^{2}$ & 1.203 & 0.647 & 1.115 & 0.411 & 1.111 & 0.478 & 1.310 & 0.811 \\
\hline \multicolumn{9}{|l|}{ Factor 3} \\
\hline Repetitive movements ${ }^{2}$ & 2.693 & 1.055 & 2.466 & 1.206 & 2.364 & 1.221 & 2.286 & 1.195 \\
\hline Monotonous tasks ${ }^{2}$ & 2.415 & 1.043 & 2.240 & 1.180 & 2.088 & 1.133 & 2.381 & 1.058 \\
\hline \multicolumn{9}{|l|}{ Factor 4} \\
\hline$\overline{\text { Work alone }^{2}}$ & 1.802 & 1.016 & 2.128 & 1.181 & 2.046 & 1.182 & 1.714 & 0.944 \\
\hline Work autonomy ${ }^{2}$ & 1.887 & 1.024 & 2.654 & 1.206 & 2.719 & 1.182 & 2.214 & 1.200 \\
\hline Discrimination & 0.322 & 0.468 & 0.166 & 0.373 & 0.114 & 0.319 & 0.155 & 0.364 \\
\hline Satisfaction working conditions ${ }^{3}$ & 2.887 & 0.686 & 2.958 & 0.695 & 3.166 & 0.631 & 3.143 & 0.608 \\
\hline
\end{tabular}

Notes: (1) This variable is in intervals. We considered the wage to be the middle point of the salary interval reported by the respondent.

(2) The codes for the variable are: 1. Never; 2. Sometimes; 3. Often; 4. Always

(3) The codes for the variable are: 1. Very dissatisfied; 2. Dissatisfied; 3. Satisfied; 4. Very satisfied 
Table 4: Test of the difference in average job satisfaction by origin

\begin{tabular}{|c|c|c|c|c|c|c|c|c|}
\hline & \multicolumn{2}{|c|}{ Catalan Spanish } & \multicolumn{2}{|c|}{$\begin{array}{c}\text { Non-Catalan } \\
\text { Spanish }\end{array}$} & \multicolumn{2}{|c|}{ African } & \multicolumn{2}{|c|}{ Latin American } \\
\hline & Diff. & t-stat. & Diff. & t-stat. & Diff. & t-stat. & Diff. & t-stat. \\
\hline Non-Catalan Spanish & -0.095 & -5.307 & & & & & & \\
\hline African & -0.224 & -5.167 & -0.129 & -2.811 & & & & \\
\hline Latin American & -0.153 & -4.517 & -0.058 & -1.549 & 0.071 & 1.189 & & \\
\hline EU15 & 0.055 & 1.282 & 0.151 & 3.341 & 0.279 & 4.387 & 0.208 & 3.597 \\
\hline
\end{tabular}


Table 5: POLS estimates of working condition satisfaction equations

\begin{tabular}{|c|c|c|c|c|c|c|}
\hline & & & \multicolumn{2}{|c|}{ Spanish-Born } & \multicolumn{2}{|c|}{ Non-Spanish born } \\
\hline & \multicolumn{2}{|c|}{ Catalan } & \multicolumn{2}{|c|}{ Non-Catalan } & \multirow[b]{2}{*}{ Coeff. } & \multirow[b]{2}{*}{$t$-sta } \\
\hline & Coeff. & $t$-stat & Coeff. & t-stat & & \\
\hline Constant & 5.080 & 6.34 & 3.412 & 1.37 & 4.959 & 1.78 \\
\hline \multicolumn{7}{|l|}{ Individual characteristics } \\
\hline $\log$ (Years of schooling) & 0.022 & 0.68 & 0.037 & 0.64 & -0.163 & -2.89 \\
\hline $\log ($ age $)$ & -1.344 & -2.95 & -0.380 & -0.28 & -0.970 & -0.61 \\
\hline log(age) squared & 0.181 & 2.83 & 0.045 & 0.25 & 0.145 & 0.64 \\
\hline $\log ($ arrival) & & & & & -0.009 & -0.29 \\
\hline woman & -0.007 & -0.47 & 0.017 & 0.50 & -0.035 & -0.72 \\
\hline \multicolumn{7}{|l|}{ Contract (base: permanent/ indefinite) } \\
\hline Fixed-term contract & -0.060 & -2.81 & -0.084 & -1.76 & -0.068 & -1.39 \\
\hline Without contract & -0.210 & -3.79 & -0.251 & -2.53 & -0.206 & -2.28 \\
\hline Self-employed & 0.081 & 4.29 & 0.029 & 0.68 & 0.110 & 1.47 \\
\hline Other & -0.176 & -1.61 & 0.192 & 0.71 & 0.309 & 0.53 \\
\hline \multicolumn{7}{|l|}{ Working time (base: fulltime split shift) } \\
\hline Fulltime morning shift & 0.000 & 0.02 & -0.029 & -0.78 & -0.012 & -0.21 \\
\hline Fulltime evening shift & -0.027 & -0.74 & -0.075 & -1.09 & -0.034 & -0.39 \\
\hline Fulltime night shift & -0.115 & -2.34 & -0.112 & -1.27 & -0.396 & -3.31 \\
\hline Fulltime rotation shift & -0.013 & -0.47 & 0.021 & 0.36 & -0.072 & -0.93 \\
\hline Fulltime Irregular or changing shift & -0.061 & -2.74 & -0.140 & -2.90 & -0.048 & -0.64 \\
\hline Part-time & -0.022 & -0.29 & 0.109 & 0.62 & -0.294 & -1.41 \\
\hline \multicolumn{7}{|l|}{ Working conditions } \\
\hline log(weekly hours worked) & -0.035 & -1.87 & -0.058 & -1.31 & -0.064 & -1.19 \\
\hline Risk of injury & -0.122 & -2.82 & -0.159 & -1.53 & -0.019 & -0.15 \\
\hline Flexible working times & 0.129 & 8.68 & 0.094 & 2.89 & 0.120 & 2.49 \\
\hline Factor 1 (dust. noise. move loads) & -0.043 & -5.60 & -0.050 & -3.25 & -0.003 & -0.13 \\
\hline Factor 2 (Rel. colleagues and superiors) & -0.065 & -9.17 & -0.045 & -3.49 & -0.051 & -2.76 \\
\hline Factor 3 (Repetitive. monotonous tasks) & -0.100 & -12.62 & -0.093 & -5.81 & -0.076 & -3.20 \\
\hline Factor 4 (Flexibility. working alone) & 0.025 & 3.39 & 0.042 & 2.82 & 0.014 & 0.63 \\
\hline Work too much & -0.064 & -7.57 & -0.073 & -4.22 & -0.137 & -5.15 \\
\hline Discriminated against at work & & & & & -0.144 & -3.23 \\
\hline \multicolumn{7}{|l|}{ Sub-region (base: Lleida) } \\
\hline Tarragona & 0.016 & 0.58 & 0.134 & 2.17 & 0.173 & 1.87 \\
\hline Tortosa & 0.104 & 3.31 & 0.205 & 2.24 & 0.001 & 0.01 \\
\hline Girona & -0.001 & -0.04 & 0.112 & 1.85 & -0.009 & -0.11 \\
\hline Costa de Ponent & -0.052 & -2.17 & -0.038 & -0.73 & -0.129 & -1.69 \\
\hline Barcelones Nord and Maresme & -0.079 & -2.59 & -0.067 & -1.05 & -0.246 & -2.44 \\
\hline Centre & -0.103 & -4.54 & -0.026 & -0.48 & -0.176 & -2.36 \\
\hline Barcelona City & -0.151 & -6.13 & -0.025 & -0.44 & -0.155 & -2.16 \\
\hline \multicolumn{7}{|l|}{ Origin (base: African) } \\
\hline$\overline{\text { Latin American }}$ & & & & & 0.063 & 1.04 \\
\hline EU15 & & & & & 0.139 & 1.90 \\
\hline Central and Eastern Europe & & & & & 0.219 & 2.56 \\
\hline Other & & & & & 0.138 & 1.22 \\
\hline R-squared (adjusted) & 0.1 & & & & & \\
\hline $\mathrm{N}$ & 6.5 & & & & & \\
\hline
\end{tabular}


Permanent Contract

Without Contract

\begin{tabular}{|c|c|c|c|c|c|c|c|c|c|c|c|c|}
\hline & & & \multirow{3}{*}{\multicolumn{2}{|c|}{ Non-Catalan }} & mere & & \multirow{2}{*}{\multicolumn{4}{|c|}{ Non-Catalan }} & (1) & Mura \\
\hline & \multirow{2}{*}{\multicolumn{2}{|c|}{ Catalan }} & & & \multirow{2}{*}{\multicolumn{2}{|c|}{ Non-Spanish }} & & & & & \multirow{2}{*}{\multicolumn{2}{|c|}{ Non-Spanish }} \\
\hline & & & & & & & \multicolumn{2}{|c|}{ Catalan } & \multicolumn{2}{|c|}{ Spanish } & & \\
\hline & m.e. & z-val. & m.e. & z-val. & \multicolumn{2}{|c|}{ m.e. $\quad$ z-val. } & m.e. & z-val. & m.e. & z-val. & m.e. & z-val. \\
\hline Years schooling & 0.010 & 5.71 & 0.014 & 4.85 & 0.015 & 3.25 & -0.004 & -9.25 & -0.005 & -6.98 & -0.013 & -6.10 \\
\hline Age & 0.019 & 10.53 & 0.003 & 3.23 & 0.002 & 0.92 & -0.002 & -5.00 & 0.001 & 3.35 & 0.000 & -0.32 \\
\hline Age squared & 0.000 & -10.68 & & & & & 0.000 & 5.37 & & & & \\
\hline YSM & & & & & 0.003 & 2.04 & & & & & -0.005 & -3.14 \\
\hline YSM squared & & & & & & & & & & & 0.000 & 2.38 \\
\hline Woman & -0.004 & -0.34 & -0.145 & -8.21 & -0.052 & -1.57 & 0.045 & 13.53 & 0.109 & 11.46 & 0.091 & 5.54 \\
\hline Household size & -0.024 & -5.44 & -0.002 & -0.27 & -0.004 & -0.35 & 0.000 & 0.50 & 0.000 & 0.19 & 0.002 & 0.40 \\
\hline Married & 0.063 & 4.39 & 0.045 & 1.54 & 0.072 & 1.92 & -0.007 & -2.04 & 0.003 & 0.43 & -0.021 & -1.33 \\
\hline Widow & 0.036 & 1.35 & -0.029 & -0.69 & 0.044 & 0.35 & -0.006 & -1.47 & 0.007 & 0.67 & 0.075 & 1.13 \\
\hline Separated & 0.029 & 0.87 & -0.030 & -0.58 & 0.007 & 0.07 & 0.001 & 0.10 & -0.009 & -0.84 & 0.069 & 1.46 \\
\hline Divorced & -0.036 & -0.89 & 0.012 & 0.18 & 0.118 & 1.25 & -0.002 & -0.26 & 0.000 & 0.00 & & \\
\hline Discrimination & & & & & -0.127 & -3.10 & & & & & 0.002 & 0.09 \\
\hline Tarragona & 0.096 & 4.78 & 0.018 & 0.48 & -0.120 & -1.73 & -0.002 & -0.38 & 0.006 & 0.52 & 0.047 & 1.27 \\
\hline Tortosa & 0.003 & 0.15 & -0.044 & -0.76 & -0.112 & -1.42 & -0.003 & -0.67 & -0.001 & -0.07 & 0.110 & 2.38 \\
\hline Girona & 0.118 & 6.63 & 0.002 & 0.05 & -0.013 & -0.21 & -0.006 & -1.66 & 0.005 & 0.49 & 0.005 & 0.17 \\
\hline Costa de Ponent & 0.138 & 7.97 & 0.058 & 1.86 & 0.074 & 1.28 & -0.005 & -1.32 & 0.016 & 1.70 & 0.021 & 0.74 \\
\hline Barcelones Nord - Maresme & 0.118 & 5.34 & -0.013 & -0.35 & -0.055 & -0.74 & -0.004 & -0.88 & 0.010 & 0.94 & -0.007 & -0.21 \\
\hline Centre & 0.159 & 9.83 & 0.076 & 2.40 & 0.043 & 0.75 & -0.003 & -0.85 & 0.008 & 0.89 & 0.070 & 2.23 \\
\hline Barcelona City & 0.162 & 9.50 & 0.036 & 1.10 & -0.045 & -0.86 & 0.007 & 1.68 & 0.016 & 1.64 & 0.031 & 1.22 \\
\hline Non-Catalan-born Spanish ${ }^{(1)}$ & 0.055 & 4.96 & & & & & 0.011 & 3.96 & & & & \\
\hline African $^{(1)}$ & -0.211 & -6.63 & & & -0.159 & -3.07 & 0.058 & 5.18 & & & -0.025 & -1.17 \\
\hline Latin American ${ }^{(1)}$ & -0.201 & -8.11 & & & -0.149 & -3.19 & 0.060 & 6.67 & & & -0.011 & -0.54 \\
\hline EU15 and wealthy countries ${ }^{(1)}$ & 0.003 & 0.10 & & & & & 0.047 & 3.73 & & & & \\
\hline Other $^{(1)}$ & -0.111 & -2.55 & & & -0.053 & -0.89 & 0.036 & 2.43 & & & -0.037 & -1.78 \\
\hline Log-likelihood & & -6449 & & -1880 & & -6811 & & -1260 & & -5920 & & -2501 \\
\hline Sample size & & 9916 & & 3087 & & 1065 & & 9916 & & 3087 & & 1032 \\
\hline Pseudo-R ${ }^{2}$ & & 0.039 & & 0.038 & & 0.066 & & 0.157 & & 0.289 & & 0.179 \\
\hline
\end{tabular}

Notes: (1) Estimated effects regarding birthplace dummies are obtained from the estimates using the full-sample. m.e. refers to marginal effects. 


\begin{tabular}{|c|c|c|c|c|c|c|c|c|c|c|c|c|}
\hline & \multicolumn{6}{|c|}{ Risk of injury/death ${ }^{(2)}$} & & & & & \multicolumn{2}{|c|}{ Flexibility } \\
\hline & \multirow{2}{*}{\multicolumn{2}{|c|}{ Catalan }} & \multirow{2}{*}{\multicolumn{2}{|c|}{$\begin{array}{r}\text { Non-Catalan } \\
\text { Spanish } \\
\end{array}$}} & \multirow{2}{*}{\multicolumn{2}{|c|}{ Non-Spanish }} & \multirow{2}{*}{\multicolumn{2}{|c|}{ Catalan }} & \multicolumn{2}{|c|}{ Non-Catalan } & \multirow{2}{*}{\multicolumn{2}{|c|}{ Non-Spanish }} \\
\hline & & & & & & & & & & anish & & \\
\hline & m.e. & t-val. & m.e. & t-val. & m.e. & t-val. & m.e. & z-val. & m.e. & z-val. & m.e. & z-val. \\
\hline Years schooling & -0.022 & -14.36 & -0.019 & -7.13 & -0.016 & -3.79 & 0.021 & 9.64 & 0.014 & 3.33 & 0.018 & 3.30 \\
\hline Age & -0.003 & -1.83 & 0.000 & -0.49 & 0.002 & 1.24 & 0.004 & 5.23 & 0.002 & 1.64 & 0.002 & 0.85 \\
\hline Age squared & 0.000 & 2.10 & & & & & & & & & & \\
\hline YSM & & & & & -0.002 & -1.21 & & & & & 0.005 & 2.24 \\
\hline \multicolumn{13}{|l|}{ YSM squared } \\
\hline Woman & -0.291 & -32.11 & -0.305 & -18.13 & -0.361 & -11.58 & -0.067 & -5.30 & 0.025 & 0.93 & 0.007 & 0.18 \\
\hline Household size & 0.006 & 1.47 & 0.003 & 0.45 & 0.013 & 1.26 & 0.000 & 0.09 & -0.006 & -0.46 & 0.004 & 0.36 \\
\hline Married & -0.005 & -0.44 & -0.027 & -0.97 & -0.065 & -1.84 & 0.031 & 1.94 & -0.005 & -0.11 & -0.003 & -0.08 \\
\hline Widow & 0.055 & 2.27 & 0.006 & 0.15 & 0.070 & 0.57 & 0.093 & 1.44 & 0.034 & 0.34 & -0.166 & -0.98 \\
\hline Separated & 0.013 & 0.43 & -0.040 & -0.81 & -0.108 & -1.10 & 0.001 & 0.02 & -0.005 & -0.07 & 0.173 & 1.60 \\
\hline Divorced & -0.010 & -0.28 & -0.028 & -0.46 & -0.059 & -0.62 & 0.068 & 1.44 & -0.128 & -1.47 & -0.043 & -0.44 \\
\hline Discrimination & & & & & 0.007 & 0.19 & & & & & -0.008 & -0.16 \\
\hline Tarragona & -0.050 & -3.06 & -0.023 & -0.70 & -0.134 & -2.35 & -0.023 & -0.89 & 0.033 & 0.58 & 0.197 & 2.43 \\
\hline Tortosa & 0.040 & 2.16 & -0.086 & -1.84 & 0.112 & 1.45 & 0.061 & 2.12 & 0.086 & 1.02 & 0.010 & 0.11 \\
\hline Girona & -0.062 & -4.33 & -0.066 & -2.12 & -0.169 & -3.67 & -0.009 & -0.39 & 0.078 & 1.39 & 0.084 & 1.22 \\
\hline Costa de Ponent & -0.069 & -4.87 & -0.105 & -3.96 & -0.122 & -2.53 & -0.007 & -0.34 & 0.091 & 1.90 & -0.015 & -0.23 \\
\hline Barcelones Nord - Maresme & -0.105 & -6.10 & -0.064 & -2.04 & -0.197 & -3.66 & -0.102 & -3.67 & 0.110 & 1.88 & 0.095 & 1.06 \\
\hline Centre & -0.061 & -4.63 & -0.098 & -3.62 & -0.185 & -4.15 & -0.070 & -3.39 & 0.067 & 1.36 & 0.071 & 1.09 \\
\hline Barcelona City & -0.104 & -7.58 & -0.095 & -3.41 & -0.175 & -3.93 & -0.021 & -0.94 & 0.062 & 1.19 & 0.167 & 2.77 \\
\hline Non-Catalan-born Spanish $^{(1)}$ & -0.016 & -1.68 & & & & & -0.092 & -6.01 & & & & \\
\hline African $^{(1)}$ & 0.164 & 5.79 & & & 0.177 & 3.37 & -0.244 & -6.71 & & & -0.176 & -3.14 \\
\hline Latin American $^{(1)}$ & 0.035 & 1.58 & & & 0.007 & 0.14 & -0.044 & -1.61 & & & 0.017 & 0.33 \\
\hline EU15 and wealthy countries ${ }^{(1)}$ & 0.005 & 0.15 & & & & & -0.019 & -0.44 & & & & \\
\hline Other $^{(1)}$ & 0.040 & 1.04 & & & 0.001 & 0.02 & -0.146 & -3.16 & & & -0.066 & -1.05 \\
\hline Log-likelihood & & -4711 & & -15541 & & -512 & & -4494 & & -9611 & & -4961 \\
\hline Sample size & & 9916 & & 3087 & & 1065 & & 6651 & & 1457 & & 836 \\
\hline Pseudo-R ${ }^{2}$ & & 0.154 & & 0.124 & & 0.225 & & 0.02 & & 0.01 & & 0.086 \\
\hline
\end{tabular}

Notes: (1) Estimated effects regarding birthplace dummies are obtained from the estimates using the full-sample; (2) The outcome variable is a dummy variable that takes the value 1 if the worker is employed in occupation-industry cell in top quartile of the injury/death distribution. m.e. refers to marginal effects. 


\begin{tabular}{|c|c|c|c|c|c|c|c|c|c|c|c|c|}
\hline & \multicolumn{6}{|c|}{ Poor environmental conditions (factor 1) } & \multicolumn{6}{|c|}{ Poor relations at the workplace (factor 2) } \\
\hline & \multicolumn{2}{|c|}{ Catalan } & \multicolumn{2}{|c|}{$\begin{array}{r}\text { Non-Catalan } \\
\text { Spanish }\end{array}$} & \multicolumn{2}{|c|}{ Non-Spanish } & \multicolumn{2}{|c|}{ Catalan } & \multicolumn{2}{|c|}{$\begin{array}{r}\begin{array}{r}\text { Non-Catalan } \\
\text { Spanish }\end{array} \\
\end{array}$} & \multicolumn{2}{|c|}{ Non-Spanish } \\
\hline & m.e. & $t-v a l$. & m.e. & $t$-val. & m.e. & $t$-val. & m.e. & t-val. & m.e. & $t$-val. & m.e. & t-val. \\
\hline Years schooling & -0.071 & -17.81 & -0.047 & -5.49 & -0.028 & -2.57 & 0.012 & 3.00 & 0.004 & 0.41 & 0.018 & 1.49 \\
\hline Age & -0.008 & -6.75 & -0.004 & -1.43 & 0.000 & 0.05 & -0.001 & -0.25 & 0.002 & 0.72 & -0.057 & -2.05 \\
\hline Age squared & & & & & & & & & & & 0.001 & 2.23 \\
\hline YSM & & & & & 0.030 & 2.27 & & & & & 0.001 & 0.22 \\
\hline YSM squared & & & & & -0.001 & -2.25 & & & & & & \\
\hline Woman & -0.451 & -19.42 & -0.529 & -9.72 & -0.684 & -8.93 & -0.050 & -2.08 & -0.013 & -0.22 & 0.024 & 0.28 \\
\hline Household size & -0.004 & -0.41 & 0.002 & 0.08 & 0.031 & 1.32 & -0.005 & -0.47 & 0.003 & 0.10 & -0.008 & -0.30 \\
\hline Married & 0.028 & 0.97 & 0.051 & 0.61 & -0.011 & -0.14 & -0.007 & -0.25 & -0.023 & -0.25 & 0.069 & 0.72 \\
\hline Widow & -0.103 & -0.85 & -0.134 & -0.66 & 0.399 & 1.01 & 0.126 & 1.01 & 0.091 & 0.40 & -0.151 & -0.34 \\
\hline Separated & 0.089 & 1.24 & 0.168 & 1.22 & -0.441 & -2.00 & -0.056 & -0.75 & -0.003 & -0.02 & 0.001 & 0.00 \\
\hline Divorced & 0.105 & 1.19 & 0.091 & 0.50 & -0.051 & -0.25 & 0.112 & 1.24 & -0.029 & -0.15 & -0.023 & -0.10 \\
\hline Discrimination & & & & & 0.179 & 1.79 & & & & & 0.500 & 4.46 \\
\hline Tarragona & -0.072 & -1.51 & 0.165 & 1.45 & -0.304 & -1.93 & 0.067 & 1.37 & 0.090 & 0.72 & 0.156 & 0.88 \\
\hline Tortosa & 0.029 & 0.55 & 0.091 & 0.54 & 0.142 & 0.82 & 0.064 & 1.16 & -0.047 & -0.25 & -0.097 & -0.50 \\
\hline Girona & 0.030 & 0.71 & 0.154 & 1.38 & -0.189 & -1.39 & 0.041 & 0.94 & 0.122 & 0.99 & 0.230 & 1.51 \\
\hline Costa de Ponent & -0.025 & -0.62 & 0.122 & 1.28 & -0.328 & -2.52 & 0.123 & 2.94 & 0.186 & 1.76 & 0.143 & 0.97 \\
\hline Barcelones Nord - Maresme & -0.037 & -0.73 & 0.209 & 1.80 & -0.285 & -1.65 & 0.135 & 2.53 & 0.078 & 0.61 & 0.109 & 0.56 \\
\hline Centre & 0.086 & 2.26 & 0.179 & 1.81 & -0.256 & -2.01 & 0.130 & 3.28 & 0.182 & 1.67 & 0.280 & 1.95 \\
\hline Barcelona City & 0.022 & 0.54 & 0.087 & 0.83 & -0.338 & -2.85 & 0.152 & 3.59 & 0.005 & 0.05 & 0.331 & 2.47 \\
\hline Non-Catalan-born Spanish ${ }^{(1)}$ & 0.099 & 3.41 & & & & & 0.035 & 1.14 & & & & \\
\hline African $^{(1)}$ & 0.148 & 2.19 & & & 0.125 & 1.03 & 0.202 & 2.83 & & & 0.155 & 1.12 \\
\hline Latin American $^{(1)}$ & -0.016 & -0.30 & & & 0.000 & 0.00 & -0.029 & -0.53 & & & -0.061 & -0.49 \\
\hline EU15 and wealthy countries ${ }^{(1)}$ & 0.016 & 0.20 & & & & & -0.035 & -0.42 & & & & \\
\hline Other $^{(1)}$ & -0.011 & -0.13 & & & -0.025 & -0.18 & 0.260 & 2.72 & & & 0.282 & 1.83 \\
\hline Constant & 1.329 & 16.05 & 0.849 & 3.95 & 0.583 & 2.39 & -0.199 & -2.32 & -0.223 & -0.94 & 0.459 & 0.81 \\
\hline Sample size & & 6618 & & 1452 & & 826 & & 6618 & & 1452 & & 826 \\
\hline Pseudo-R ${ }^{2}$ & & 0.110 & & 0.089 & & 0.156 & & 0.006 & & 0.005 & & 0.032 \\
\hline
\end{tabular}




\begin{tabular}{|c|c|c|c|c|c|c|c|c|c|c|c|c|}
\hline & \multicolumn{6}{|c|}{ Monotonous tasks (factor 3) } & \multicolumn{6}{|c|}{ Autonomy in the workplace (factor 4) } \\
\hline & \multirow{2}{*}{\multicolumn{2}{|c|}{ Catalan }} & \multirow{2}{*}{\multicolumn{2}{|c|}{$\begin{array}{r}\text { Non-Catalan } \\
\text { Spanish } \\
\end{array}$}} & \multirow{2}{*}{\multicolumn{2}{|c|}{ Non-Spanish }} & \multirow{2}{*}{\multicolumn{2}{|c|}{ Catalan }} & \multirow{2}{*}{\multicolumn{2}{|c|}{$\begin{array}{c}\text { Non-Catalan } \\
\text { Spanish }\end{array}$}} & \multirow{2}{*}{\multicolumn{2}{|c|}{ Non-Spanish }} \\
\hline & & & & & & & & & & & & \\
\hline & m.e. & $t$-val. & m.e. & $t$-val. & m.e. & t-val. & m.e. & t-val. & m.e. & $t$-val. & m.e. & $t$-val. \\
\hline Years schooling & -0.083 & -20.03 & -0.092 & -10.47 & -0.040 & -3.79 & 0.003 & 0.70 & -0.015 & -1.74 & 0.031 & 2.82 \\
\hline Age & 0.014 & 2.00 & -0.004 & -1.43 & -0.001 & -0.28 & 0.023 & 3.28 & 0.006 & 1.85 & 0.003 & 0.64 \\
\hline Age squared & -0.000 & -2.25 & & & & & -0.000 & -2.13 & & & & \\
\hline YSM & & & & & -0.012 & -2.74 & & & & & 0.010 & 2.32 \\
\hline \multicolumn{13}{|l|}{ YSM squared } \\
\hline Woman & 0.089 & 3.72 & 0.279 & 5.01 & 0.207 & 2.75 & -0.150 & -6.14 & -0.077 & -1.38 & 0.056 & 0.74 \\
\hline Household size & -0.008 & -0.80 & -0.009 & -0.36 & 0.019 & 0.81 & 0.002 & 0.23 & -0.027 & -1.05 & -0.026 & -1.11 \\
\hline Married & -0.043 & -1.36 & 0.118 & 1.37 & 0.084 & 1.04 & 0.0428 & 1.28 & -0.084 & -0.98 & 0.003 & 0.04 \\
\hline Widow & 0.113 & 0.92 & 0.229 & 1.09 & 0.028 & 0.07 & 0.017 & 0.14 & -0.160 & -0.77 & 0.182 & 0.46 \\
\hline Separated & -0.018 & -0.24 & 0.161 & 1.15 & -0.129 & -0.60 & -0.024 & -0.31 & 0.124 & 0.89 & 0.203 & 0.92 \\
\hline Divorced & 0.042 & 0.46 & -0.040 & -0.21 & -0.047 & -0.23 & 0.018 & 0.19 & -0.246 & -1.33 & 0.129 & 0.62 \\
\hline Discrimination & & & & & 0.060 & 0.61 & & & & & -0.027 & -0.27 \\
\hline Tarragona & 0.148 & 3.04 & 0.074 & 0.64 & 0.034 & 0.22 & -0.147 & -2.94 & -0.248 & -2.14 & 0.010 & 0.06 \\
\hline Tortosa & 0.116 & 2.13 & -0.013 & -0.08 & 0.144 & 0.84 & 0.000 & 0.00 & -0.332 & -1.94 & 0.091 & 0.52 \\
\hline Girona & 0.135 & 3.11 & 0.304 & 2.66 & -0.033 & -0.25 & -0.084 & -1.87 & -0.260 & -2.30 & -0.047 & -0.35 \\
\hline Costa de Ponent & 0.154 & 3.71 & 0.080 & 0.82 & 0.037 & 0.29 & -0.309 & -7.23 & -0.243 & -2.51 & -0.051 & -0.39 \\
\hline Barcelones Nord - Maresme & 0.284 & 5.38 & 0.117 & 0.98 & -0.039 & -0.23 & -0.192 & -3.54 & -0.116 & -0.98 & 0.262 & 1.51 \\
\hline Centre & 0.135 & 3.47 & 0.132 & 1.30 & -0.105 & -0.84 & -0.141 & -3.51 & -0.170 & -1.69 & 0.071 & 0.56 \\
\hline Barcelona City & 0.256 & 6.10 & 0.273 & 2.53 & 0.231 & 1.98 & -0.186 & -4.31 & -0.287 & -2.69 & 0.175 & 1.47 \\
\hline Non-Catalan-born Spanish ${ }^{(1)}$ & 0.148 & 4.98 & & & & & -0.109 & -3.60 & & & & \\
\hline African $^{(1)}$ & 0.268 & 3.90 & & & 0.242 & 2.02 & -0.649 & -9.25 & & & -0.266 & -2.18 \\
\hline Latin American $^{(1)}$ & 0.266 & 5.03 & & & 0.043 & 0.40 & -0.056 & -1.03 & & & 0.141 & 1.28 \\
\hline EU15 and wealthy countries ${ }^{(1)}$ & 0.060 & 0.75 & & & & & -0.137 & -1.66 & & & & \\
\hline Other $^{(1)}$ & 0.107 & 1.16 & & & -0.118 & -0.88 & -0.285 & -3.02 & & & -0.010 & -0.07 \\
\hline Constant & 0.568 & 3.93 & 1.060 & 4.81 & 0.512 & 2.19 & -0.428 & -2.87 & 0.266 & 1.22 & -0.779 & -3.28 \\
\hline Sample size & & 6618 & & 1452 & & 826 & & 6618 & & 1452 & & 826 \\
\hline Pseudo- $^{2}$ & & 0.061 & & 0.089 & & 0.047 & & 0.031 & & 0.010 & & 0.068 \\
\hline
\end{tabular}




\begin{tabular}{|c|c|c|c|c|c|c|c|c|}
\hline & \multicolumn{6}{|c|}{ Work too much } & \multicolumn{2}{|c|}{ Discrimination } \\
\hline & \multicolumn{2}{|c|}{ Catalan } & \multicolumn{2}{|c|}{$\begin{array}{r}\text { Non-Catalan } \\
\text { Spanish }\end{array}$} & \multicolumn{2}{|c|}{ Non-Spanish } & \multicolumn{2}{|c|}{ Non-Spanish } \\
\hline & m.e. & $t$-val. & m.e. & t-val. & m.e. & t-val. & m.e & $z$-val \\
\hline Years schooling & -0.022 & -5.26 & -0.006 & -0.75 & -0.034 & -3.37 & -0.008 & -1.70 \\
\hline Age & 0.031 & 4.54 & -0.004 & -1.32 & 0.003 & 0.75 & -0.001 & -0.29 \\
\hline Age squared & -0.000 & -4.49 & & & & & & \\
\hline YSM & & & & & 0.022 & 1.84 & -0.004 & -2.66 \\
\hline YSM squared & & & & & -0.001 & -2.24 & & \\
\hline Woman & -0.155 & -6.55 & -0.162 & -2.98 & -0.028 & -0.40 & -0.023 & -0.71 \\
\hline Household size & -0.015 & -1.43 & 0.016 & 0.64 & -0.061 & -2.83 & -0.034 & -3.26 \\
\hline Married & 0.063 & 2.03 & 0.114 & 1.36 & 0.217 & 2.88 & 0.044 & 1.22 \\
\hline Widow & 0.054 & 0.44 & 0.192 & 0.94 & 0.078 & 0.22 & -0.023 & -0.18 \\
\hline Separated & 0.098 & 1.32 & 0.180 & 1.30 & -0.166 & -0.82 & 0.222 & 2.27 \\
\hline Divorced & 0.047 & 0.52 & -0.074 & -0.40 & 0.045 & 0.24 & 0.076 & 0.82 \\
\hline Discrimination & & & & & 0.234 & 2.57 & & \\
\hline Tarragona & -0.013 & -0.28 & -0.088 & -0.77 & -0.023 & -0.16 & 0.031 & 0.45 \\
\hline Tortosa & -0.016 & -0.29 & -0.254 & -1.51 & -0.137 & -0.85 & 0.159 & 2.00 \\
\hline Girona & 0.075 & 1.75 & 0.152 & 1.37 & -0.165 & -1.33 & -0.098 & -1.67 \\
\hline Costa de Ponent & 0.036 & 0.88 & 0.035 & 0.37 & -0.082 & -0.68 & -0.010 & -0.19 \\
\hline Barcelones Nord - Maresme & 0.238 & 4.55 & 0.041 & 0.35 & 0.164 & 1.03 & -0.142 & -1.92 \\
\hline Centre & 0.204 & 5.28 & 0.140 & 1.41 & -0.072 & -0.62 & -0.082 & -1.47 \\
\hline Barcelona City & 0.178 & 4.28 & 0.103 & 0.98 & -0.098 & -0.90 & 0.069 & 1.34 \\
\hline Non-Catalan-born Spanish & 0.025 & 0.86 & & & & & & \\
\hline African & 0.110 & 1.63 & & & 0.197 & 1.76 & 0.295 & 5.66 \\
\hline Latin American & -0.022 & -0.43 & & & 0.157 & 1.55 & 0.076 & 1.62 \\
\hline EU15 and wealthy countries & -0.187 & -2.36 & & & & & & \\
\hline Other & -0.121 & -1.34 & & & 0.032 & 0.25 & -0.023 & -0.38 \\
\hline Constant & 1.233 & 8.60 & 1.810 & 8.40 & 1.799 & 8.04 & 0.806 & 7.98 \\
\hline Sample size & & 6618 & & 1452 & & 826 & & 1014 \\
\hline Pseudo-R ${ }^{2}$ & & 0.024 & & 0.011 & & 0.051 & & 0.083 \\
\hline
\end{tabular}

Notes: (1) Estimated effects regarding birthplace dummies are obtained from the estimates using the full-sample. m.e. refers to marginal effects. 